\title{
Immuno-PET imaging of PD-L1 expression in patient-derived lung cancer xenografts with $\left[{ }^{68} \mathrm{Ga}\right] \mathrm{Ga}-\mathrm{NOTA}-\mathrm{Nb} 109$
}

\author{
Qingzhu Liu ${ }^{1 \#}$, Xiaodan Wang ${ }^{2 \#}$, Yanling Yang ${ }^{3}$, Chao Wang ${ }^{3}$, Jian Zou ${ }^{4}$, Jianguo Lin ${ }^{1,5}$, Ling Qiu ${ }^{1,5}$ \\ ${ }^{1}$ NHC Key Laboratory of Nuclear Medicine, Jiangsu Key Laboratory of Molecular Nuclear Medicine, Jiangsu Institute of Nuclear Medicine, Wuxi, \\ China; ${ }^{2}$ Wuxi Second Hospital Affiliated to Nanjing Medical University, Wuxi, China; ${ }^{3}$ Suzhou Smart Nuclide Biopharmaceutical Co. Ltd., Suzhou \\ Industrial Park, Suzhou, China; ${ }^{4}$ Center of Clinical Research, The Affiliated Wuxi People's Hospital of Nanjing Medical University, Wuxi, China; \\ ${ }^{5}$ Department of Radiopharmaceuticals, School of Pharmacy, Nanjing Medical University, Nanjing, China
}

Contributions: (I) Conception and design: L Qiu, J Lin, J Zou; (II) Administrative support: L Qiu, J Lin, J Zou; (III) Provision of study materials or patients: Q Liu, X Wang, Y Yang; (IV) Collection and assembly of data: Q Liu, X Wang; (V) Data analysis and interpretation: Q Liu, X Wang, C Wang; (VI) Manuscript writing: All authors; (VII) Final approval of manuscript: All authors.

\#These authors contributed equally to this work.

Correspondence to: Ling Qiu. NHC Key Laboratory of Nuclear Medicine, Jiangsu Key Laboratory of Molecular Nuclear Medicine, Jiangsu Institute of Nuclear Medicine, 20 Qianrong Road, Wuxi 214063, China. Email: qiuling@jsinm.org; Jianguo Lin. NHC Key Laboratory of Nuclear Medicine, Jiangsu Key Laboratory of Molecular Nuclear Medicine, Jiangsu Institute of Nuclear Medicine, 20 Qianrong Road, Wuxi 214063 , China. Email: linjianguo@jsinm.org; Jian Zou. Center of Clinical Research, The Affiliated Wuxi People’s Hospital of Nanjing Medical University, 299 Qingyang Road, Wuxi 214023, China. Email: zoujan@njmu.edu.cn.

Background: Accurate evaluation of programmed death-ligand 1 (PD-L1) expression levels in cancer patients may be useful in the identification of potential candidates for anti-programmed death-1/PDL1 (anti-PD-1/PD-L1) immune checkpoint therapy to improve the response rate of immune checkpoint blockade therapy. This study evaluated the feasibility of the nanobody-based positron emission tomography (PET) tracer $\left[{ }^{68} \mathrm{Ga}\right] \mathrm{Ga}-\mathrm{NOTA}-\mathrm{Nb} 109$ for immuno-PET imaging of PD-L1 in lung cancer patient-derived xenograft (PDX).

Methods: We constructed 2 PDXs of lung adenocarcinoma (ADC) and lung squamous cell carcinoma (SCC) and used them for immuno-PET imaging. A 2-hour dynamic PET scanning was performed on the samples and the in vivo biodistribution and metabolism of $\left[{ }^{68} \mathrm{Ga}\right] \mathrm{Ga}-\mathrm{NOTA}-\mathrm{Nb} 109$ were investigated using region of interest (ROI) analysis. The ex vivo biodistribution of $\left[{ }^{68} \mathrm{Ga}\right] \mathrm{Ga}-\mathrm{NOTA}-\mathrm{Nb} 109$ in the 2 PDXs was investigated by static PET scanning. In addition, tumor PD-L1 expression in the 2 PDXs was evaluated by autoradiography, western blot, and immunohistochemical (IHC) analysis.

Results: Noninvasive PET imaging showed that $\left[{ }^{68} \mathrm{Ga}\right] \mathrm{Ga}-\mathrm{NOTA}-\mathrm{Nb} 109$ can accurately and sensitively assess the PD-L1 expression in non-small cell lung cancer (NSCLC) PDX models. The maximum [ $\left.{ }^{68} \mathrm{Ga}\right]$ Ga-NOTA-Nb109 uptake by the ADC PDX LU6424 and the SCC PDX LU6437 were 3.13\% $0.35 \%$ and $2.60 \% \pm 0.32 \%$ injected dose per milliliter of tissue volume (ID/mL), respectively, at 20 min post injection. In vivo and ex vivo biodistribution analysis showed that $\left[{ }^{68} \mathrm{Ga}\right] \mathrm{Ga}-\mathrm{NOTA}-\mathrm{Nb} 109$ was rapidly cleared through renal excretion and an enhanced signal-to-noise ratio (SNR) was achieved. Ex vivo PD-L1 expression analysis showed good agreement with in vivo PET imaging results.

Conclusions: This study demonstrated that $\left[{ }^{68} \mathrm{Ga}\right] \mathrm{Ga}-\mathrm{NOTA}-\mathrm{Nb} 109$ could be applied with PET imaging to noninvasively and accurately monitor PD-L1 expression in vivo for screening patients who may be responsive to immunotherapy and to guide the development of appropriate treatment strategies for such patients. 
Keywords: PD-L1 expression; lung cancer; immuno-PET imaging; patient-derived xenograft (PDX); immunotherapy

Submitted Oct 09, 2021. Accepted for publication Jan 17, 2022.

doi: 10.21037/qims-21-991

View this article at: https://dx.doi.org/10.21037/qims-21-991

\section{Introduction}

Lung cancer remains the most common cause of cancerrelated deaths worldwide, comprising $18 \%$ of the total number. According to the latest global cancer statistics, after female breast cancer, lung cancer is the second most frequently diagnosed cancer ( $11.7 \%$ vs. $11.4 \%)$ (1). While surgery is the primary form of treatment for early lung cancer, most patients present with metastasis at the time of initial diagnosis, resulting in poor prognosis. Radiotherapy is commonly used for the treatment of local advanced lung cancer that is not suitable for surgery. However, there are several disadvantages to radiotherapy, including a high risk of toxicity to surrounding normal tissues, radiation pneumonitis, injury to nerves, and skin toxicity, as well as complicated efficacy evaluation due to inflammation around the tumor after radiotherapy (2). Chemotherapy is another common treatment strategy for lung cancer, especially in patients with advanced non-small cell lung cancer (NSCLC). Platinum-based chemotherapy is generally the first-line treatment for metastatic lung cancer $(3,4)$. While molecular targeted therapies can significantly improve the survival rate of patients with lung cancer, drug resistance tends to be inevitable (5). Although many potent therapies are available clinically, the 5 -year survival rate for patients with lung cancer remains low (only 10-20\%) (6).

Immunotherapy has become a promising clinical strategy for treating cancers in recent years, including cytokine-based therapies such as interferon (IFN)- $\alpha$ and interleukin (IL)-2 $(7,8)$; immune checkpoint blockade therapy such as cytotoxic T-lymphocyte-associated antigen 4 (CTLA4), programmed cell death-protein 1 (PD-1), and programmed death ligand-1 (PD-L1) $(9,10)$; and engineered T cell therapy such as chimeric antigen receptor (CAR) $\mathrm{T}$ cells (11). In the last decade, many immunotherapy drugs have been approved for clinical application or preclinical research. Compared with traditional treatment, immunotherapy has shown better specificity and safety. Among various immunotherapies, anti-PD-1/PD-L1 immune checkpoint therapy has shown great success for patients with melanoma, bladder cancer, prostate cancer, and lung cancer, and as such, there has been extensive research related to the PD-1/PD-L1 pathway (12-17). Immunosuppressive antibodies, such as nivolumab, pembrolizumab, and atezolizumab, have shown remarkable efficacy in the treatment of lung cancer (18-20). There is much clinical evidence suggesting that the immunotherapy response rate is associated with the PD-1/PD-L1 expression levels in patients (21). In lung cancer patients, while the overall response rate (ORR) to anti-PD-1/PD-L1 antibodies is approximately $20-40 \%$, patients with $\mathrm{PD}-1 / \mathrm{PD}-\mathrm{L} 1$ expression greater than $50 \%$ show response rates as high as $90 \%(13,22-24)$. The tumor PD-L1 expression in NSCLC patients can be as high as $57 \%(25,26)$. Therefore, PDL1 expression may be an effective biomarker to screen lung cancer patients who may benefit significantly from immunosuppressive therapy.

The accurate and timely detection of PD-L1 expression level is essential for improving the survival rate and prognosis of lung cancer patients. Immunohistochemistry (IHC) has served as the gold standard for PD-L1 detection in clinics for a long time, and is recommended in the National Comprehensive Cancer Network (NCCN) guideline as a complementary diagnostic method for NSCLC patients receiving immunotherapy (27). However, the reagents approved for PD-L1 IHC testing are diverse, and the correlation and consistency across different platforms and reagents are controversial $(28,29)$. In addition, the expression of PD-L1 may be regulated by tumor progression and the tumor microenvironment, which presents a dynamic change in vivo (21). Hence, tumor biopsies rarely provide an accurate and real-time assessment of PD-L1 expression, especially in patients with tumor metastasis. Fortunately, non-invasive molecular imaging techniques allow for the targeted detection of PD-L1 expression in vivo repeatedly, and many tracers labeled with different radionuclides have shown promising application in preclinical studies (30).

Compared with other imaging techniques, positron emission tomography (PET) is widely used in clinical tumor detection due to its high sensitivity, spatial resolution, accurate quantification, and safety. To date, most PET 
tracers targeting PD-L1 have been developed based on PDL1 monoclonal antibodies (mAbs), such as ${ }^{64} \mathrm{Cu}$-labeled atezolizumab $(31),{ }^{89} \mathrm{Zr}$-labeled atezolizumab (32), and ${ }^{89} \mathrm{Zr}$ labeled avelumab (33), and thus, show targeted specificity to PD-L1 in vitro and in vivo. Novel PET tracers have been designed and developed to improve upon the biological performance of mAb-based tracers. These include engineered single domain antibody-based tracers such as $\left[{ }^{89} \mathrm{Zr}\right] \mathrm{Zr}-\mathrm{DFO}-\mathrm{Bz}-\mathrm{NCS}-\mathrm{KN} 035$ (34), polypeptide-based tracers such as ${ }^{64} \mathrm{Cu} /{ }^{68} \mathrm{Ga}$-labeled DOTAGA-WL12 $(35,36)$, and small molecule-based tracers such as $\left[{ }^{18} \mathrm{~F}\right] \mathrm{LG}-1$ (37) and $\left[{ }^{18} \mathrm{~F}\right] \mathrm{LN}(38)$.

In our previous research $(39,40)$, a nanobody-based PET tracer $\left[{ }^{68} \mathrm{Ga}\right] \mathrm{Ga}-\mathrm{NOTA}-\mathrm{Nb} 109$ was developed, and in vivo $\mathrm{PET}$ imaging was performed in mice harboring A375-hPD-L1 (human PD-L1 gene-transfected melanoma cells), U87 (human glioblastoma cell line), HCT 116 (human colorectal cancer cell lines), and NCI-H1299 (human non-small cell lung tumor cells) tumors. Not only did $\left[{ }^{68} \mathrm{Ga}\right] \mathrm{Ga}$-NOTA-Nb109 show high specificity to PD$\mathrm{L} 1$, but it was also able to monitor the dynamic changes in PD-L1 expression induced by chemotherapy. These studies presented a method to screen patients who may be responsive to immunotherapy and thus, may provide guidance for the formulation of appropriate treatment strategies for lung cancer patients, such as a combination of chemotherapy and immunotherapy, intervention of immunotherapy at suitable time points, and so on.

The present study further evaluated the clinical value of $\left[{ }^{68} \mathrm{Ga}\right] \mathrm{Ga}-\mathrm{NOTA}-\mathrm{Nb} 109$ in assessing PD-L1 expression in patient-derived xenografts (PDXs) by immuno-PET imaging. The biodistribution and metabolism of $\left[{ }^{68} \mathrm{Ga}\right]$ Ga-NOTA-Nb109 in the PDXs were also examined in vivo and ex vivo. This study will further contribute to the robust preclinical and clinical translational research of $\left[{ }^{68} \mathrm{Ga}\right] \mathrm{Ga}$-NOTA-Nb109 immuno-PET imaging in the effective screening of patients who may be responsive to immunotherapy and improve the overall cure rate of lung cancer patients. We present the following article in accordance with the Guidelines for Reporting Reliability and Agreement Studies (GRRAS) reporting checklist (available at https://qims.amegroups.com/article/ view/10.21037/qims-21-991/rc).

\section{Methods}

\section{Preparation of $\left[{ }^{68} \mathrm{Ga}\right] \mathrm{Ga}-\mathrm{NOTA}-\mathrm{Nb} 109$}

The radiolabeling and quality control of $\left[{ }^{68} \mathrm{Ga}\right] \mathrm{Ga}-\mathrm{NOTA}-$
Nb109 were performed as previously described $(39,40)$. Briefly, no-carrier-added $\left[{ }^{68} \mathrm{Ga}\right]$ gallium was obtained from the ${ }^{68} \mathrm{Ge} /{ }^{68} \mathrm{Ga}$ generator [Isotope Technologies Garching (ITG), GmbH, Munich, Germany) using $\mathrm{HCl}$ buffer (0.05 $\mathrm{mM})$ and the $\mathrm{pH}$ value was regulated to 4 with sodium acetate buffer $(0.25 \mathrm{M})$. The radioactive solution $(\sim 300$ $\mathrm{MBq}$ ) was mixed with 60-80 $\mu \mathrm{g}$ NOTA-Nb109 precursor for $15 \mathrm{~min}$ at $37^{\circ} \mathrm{C}$. The crude product was purified using a PD-10 column (GE Healthcare Life Sciences, Chicago, USA). The quality control evaluation was performed via radio-high-performance liquid chromatography (HPLC; RCY $>95 \%$, molar activity $=25.17 \pm 3.26 \mathrm{GBq} / \mu \mathrm{mol})$. The tracer was formulated in physiological saline prior to in vivo experiments.

\section{Construction of the PDX models}

This study was approved by the Institutional Ethics Board of Jiangsu Institute of Nuclear Medicine, in compliance with the Laboratory Animal Guidelines for the Ethical Review of Animal Welfare of China (No. GB/T 35892 2018). Mice were housed in a specific-pathogen free (SPF) grade animal laboratory regulated to $26 \pm 2{ }^{\circ} \mathrm{C}, 55 \% \pm 10 \%$ relative humidity, and a 12 -h light/dark cycle. All mice (3-5 mice per cage) were provided with animal corn cob bedding and sufficient sterile food and drinking water. Lung cancer PDXs, including adenocarcinoma (ADC) PDX LU6424 and squamous cell carcinoma (SCC) PDX LU6437, were obtained from CrownBio (Suzhou, China). For PDX construction, 4-6-week-old female BALB/c nude mice ( $\mathrm{n}=8$ per group) were subcutaneously implanted with lung tumor pieces $\left(1-2 \mathrm{~mm}^{3}\right)$ via trocar at the right forelimb armpit. Tumor growth in each PDX was monitored regularly. When the tumor volume reached $200-500 \mathrm{~mm}^{3}$ (about 25 and 50 days for LU6437 and LU6424, respectively), the PDXs were used for immuno-PET imaging and biodistribution studies.

\section{Immuno-PET imaging}

The PET imaging of the PDXs ( $\mathrm{n}=3$ for LU6424 and $\mathrm{n}=5$ for LU6437) was performed on a micro-PET scanner (Siemens Medical Solutions, Erlangen, Germany) following intravenous injection of approximately $4.0 \mathrm{MBq}\left[{ }^{68} \mathrm{Ga}\right]$ Ga-NOTA-Nb109 $(100 \mu \mathrm{L})$. Mice were anaesthetized under $2.0 \%$ isoflurane during the entire imaging process. Dynamic PET scanning images were acquired for $120 \mathrm{~min}$ and binned into 12 frames with an interval of $10 \mathrm{~min}$. Each 
frame was reconstructed using the three-dimensional (3D) ordered subset expectation maximum (OSEM) algorithm. Image analysis of the tracer in the tumor and other tissues was performed by drawing regions of interest (ROIs), and the uptake of the tracer in each tissue was quantified and expressed as the percent injected dose per milliliter of tissue volume $(\% \mathrm{ID} / \mathrm{mL})$.

\section{Biodistribution studies}

The lung cancer PDXs LU6424 ( $\mathrm{n}=3)$ and LU6437 $(\mathrm{n}=5)$, were injected intravenously with $3.7 \mathrm{MBq}\left[{ }^{68} \mathrm{Ga}\right]$ Ga-NOTA-Nb109. The mice were euthanized with $\mathrm{CO}_{2}$ asphyxiation 1 hour post-injection. Tissue samples of the heart, lung, liver, stomach, spleen, intestine, kidney, and tumor were excised, collected, and transferred to the microPET scanner for $10 \mathrm{~min}$ static scanning. The uptake of $\left[{ }^{68} \mathrm{Ga}\right] \mathrm{Ga}-\mathrm{NOTA}-\mathrm{Nb} 109$ in the tumor and normal tissues was quantified according to the ROI analysis of the PET images. The radioactivity of the tracer at the time of measurement was corrected using the following formula: $\mathrm{A}_{\Delta \mathrm{t}}=\mathrm{A}_{0} \times 0.5^{\Delta \mathrm{t} / 68}$, where $\mathrm{A}_{\Delta \mathrm{t}}$ and $\mathrm{A}_{0}$ represent the decaycorrected radioactivity and the injected radioactivity, respectively, and $\Delta t$ represents the time interval from injection to scanning.

\section{Western blot analysis of PD-L1 expression}

Tumor or muscle tissues were obtained from the mice xenografts (LU6424 and LU6437) and ground in $200 \mu \mathrm{L}$ radio immunoprecipitation Assay (RIPA) cell lysates buffer using a high-throughput tissue grinder (Scientz-48; Ningbo, China). The protein content of each sample was estimated using the BCA method and $50 \mu \mathrm{g}$ of protein was separated on a $15 \%$ sodium dodecyl sulphate-polyacrylamide gel electrophoresis (SDS-PAGE) gel. The protein was immobilized onto a polyvinylidene fluoride (PVDF) membrane, activated with methanol, and blocked with skimmed milk at room temperature. The membrane was then incubated with an anti-PD-L1 antibody (1:500, \#ab213524, Abcam, Cambridge, UK) and an anti- $\beta$-actin antibody (1:1,000, \#AF5001, Beyotime Biotechnology, Shanghai, China) overnight at $4{ }^{\circ} \mathrm{C}$. After washing in Tris buffered saline with Tween 20 (TBST), the membrane was incubated with the corresponding secondary antibody. Finally, the protein bands were visualized using electrochemiluminescence (ECL) reagents and a gel image system (Bio-Rad, Hercules, CA, USA; ChemiDoc XRS+). Quantitative analysis of each band was performed using the ImageJ software (National Institutes of Health, Bethesda, MD, USA).

\section{IHC analysis}

Fresh tumor specimens ( $\mathrm{n}=3$ for LU6424 and $\mathrm{n}=5$ for LU6437) were harvested from the mice and placed in $10 \%$ neutral-buffered formalin for overnight fixation at $4{ }^{\circ} \mathrm{C}$. Tissue sections $(3-5 \mathrm{~mm})$ were dehydrated with different volume fractions of ethanol (70-100\%) and embedded in paraffin and cooled to harden. Paraffinembedded blocks were sectioned into $4 \mu \mathrm{m}$ thickness, placed onto glass slides and dried. The paraffin sections were deparaffinized, hydrated, antigen retrieved with citric acid, and blocked with $1 \%$ bovine serum albumin (BSA) for 1 hour. Sections were then incubated with the antiPD-L1-antibody (EPR19759) (1:100, \#ab213524, Abcam, Cambridge, UK) overnight at $4{ }^{\circ} \mathrm{C}$, followed by staining with the rabbit specific IHC Polymer Detection Kit HRP/ DAB (\#ab209101, Abcam, Cambridge, UK) as per the manufacturer's protocol. All stained sections were scanned with the NanoZoomer-HT 2.0 Image system (Hamamatsu, Shizuoka, Japan) at $40 \times$ magnification.

\section{Autoradiography analysis}

Mice were euthanized by $\mathrm{CO}_{2}$ asphyxiation 1 hour after injection of 3.7 MBq $\left[{ }^{68} \mathrm{Ga}\right] \mathrm{Ga}-\mathrm{NOTA}-\mathrm{Nb} 109$, immediately dissected, and the tumor and muscle tissues were harvested. The tissues were snap-frozen by submersion in liquid nitrogen and acclimated to $-20^{\circ} \mathrm{C}$ for $20 \mathrm{~min}$ to avoid tissue shattering. The frozen sections of $20 \mu \mathrm{m}$ thickness were collected from 3 different cross section samples of each tissue and placed on slides. The slides were exposed to a phosphor storage screen film for 3 hours, and analyzed using a phosphor imager (Cyclone PLUS, PerkinElmer, Waltham, MA, USA). The relative optical density (ROD) per specific area of the selected ROI was measured and the average background signal from every ROD value of each ROI was subtracted. The amount of radioactivity was expressed as digital light units (DLU)/ $\mathrm{mm}^{2}$.

\section{Data analysis}

To minimize any potential operator subjective bias, the blinding method was applied during the data collection and analysis process, including the PET scan, autoradiography, western blot, and IHC. 
Table 1 Characteristics of the patient-derived lung cancer xenografts

\begin{tabular}{lccccccc}
\hline Models & Cancer type & Subtype & Age (years) & Gender & Pathology QC & CD274 gene expression ${ }^{1}$ \\
\hline LU6424 & NSCLC & ADC & 64 & F & Poorly differentiated ADC (P9) & 5.3041 \\
LU6437 & NSCLC & SCC & 59 & F & Poorly differentiated SCC (P3, P7) & 5.3537 \\
\hline
\end{tabular}

${ }^{1}$, CD274 gene expression was measured with RNA-seq, and shown with log2 (FPKM, Fragments Per Kilobase of exon model per Million mapped fragments). QC, quality control; NSCLC, non-small cell lung cancer; ADC, adenocarcinoma; SCC, squamous cell carcinoma; F, female.
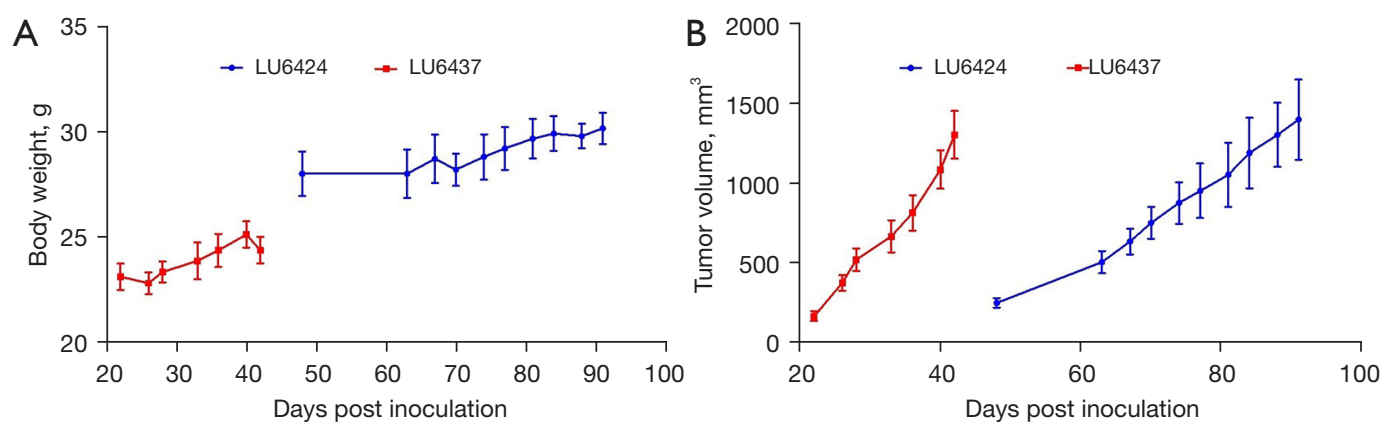

Figure 1 Construction of the lung cancer PDXs. The (A) body weight and (B) tumor volume of the 2 PDXs of lung cancer, LU6424 and LU6437, were assessed. PDX, patient-derived xenograft.

All experiments were performed in triplicates and data are expressed as mean \pm standard deviation (SD). The statistical significance between groups was analyzed using the $t$-test and one-way analysis of variance (ANOVA) test. A $\mathrm{P}$ value $<0.05$ was considered statistically significant.

\section{Results}

\section{Construction and characteristics of the PDXs}

In this study, PDX models were used to evaluate the efficacy of $\left[{ }^{68} \mathrm{Ga}\right] \mathrm{Ga}-\mathrm{NOTA}-\mathrm{Nb} 109$ in monitoring PD-L1 expression in the individual patient tumors. The morbidity and mortality associated with lung cancer remains high worldwide. Among lung cancers, NSCLC accounts for about $85 \%$, with ADC and SCC being the most common types of NSCLC $(41,42)$. Therefore, lung tumor samples obtained from ADC and SCC patients were selected to construct the PDX models. Characteristics of the lung cancer PDXs are listed in Table 1 and the growth profile of the PDXs are shown in Figure 1. The body weight of the mice carrying the PDXs varied slightly (Figure $1 A$ ), but the tumor volume increased significantly in both PDX models (Figure 1B). A comparison of the 2 PDXs showed that the growth rate of LU6424 was faster than that of LU6437, indicating that $\mathrm{ADC}$ was more malignant than SCC. This was consistent with the clinical pathological diagnosis of $\mathrm{ADC}$ and SCC (43).

\section{Immuno-PET imaging of the PDXs}

To evaluate the ability of $\left[{ }^{68} \mathrm{Ga}\right] \mathrm{Ga}-\mathrm{NOTA}-\mathrm{Nb} 109$ to monitor PD-L1 expression in vivo, immuno-PET imaging of the PDXs was performed. Dynamic PET scanning of the PDXs was performed for 2 hours after the injection of 4.0 MBq $\left[{ }^{68} \mathrm{Ga}\right] \mathrm{Ga}-\mathrm{NOTA}-\mathrm{Nb} 109$ via the tail vein. With the PDX LU6424 mice, rapid clearance of the probe in the non-target tissues was observed, and the contrast of the radiation signal at the tumor site was gradually enhanced until the end of PET scanning (Figure 2A). According to the ROI analysis, the maximum $\left[{ }^{68} \mathrm{Ga}\right] \mathrm{Ga}-\mathrm{NOTA}-\mathrm{Nb} 109$ uptake by the tumor was $3.13 \% \pm 0.35 \% \mathrm{ID} / \mathrm{mL}$ at $20 \mathrm{~min}$ post-injection (Figure $2 B$ ). Although $\left[{ }^{68} \mathrm{Ga}\right] \mathrm{Ga}-\mathrm{NOTA}$ Nb109 uptake by the tumor decreased gradually with the passage of time, the minimum accumulation of $\left[{ }^{68} \mathrm{Ga}\right]$ Ga-NOTA-Nb109 was still greater than $1 \% \mathrm{ID} / \mathrm{mL}$ at $120 \mathrm{~min}$ post-injection. The accumulation of the radiotracer in the muscles was significantly lower than that in the tumor (less than $0.30 \% \mathrm{ID} / \mathrm{mL}$ at $50 \mathrm{~min}$ post-injection) with the maximum uptake in the muscles 

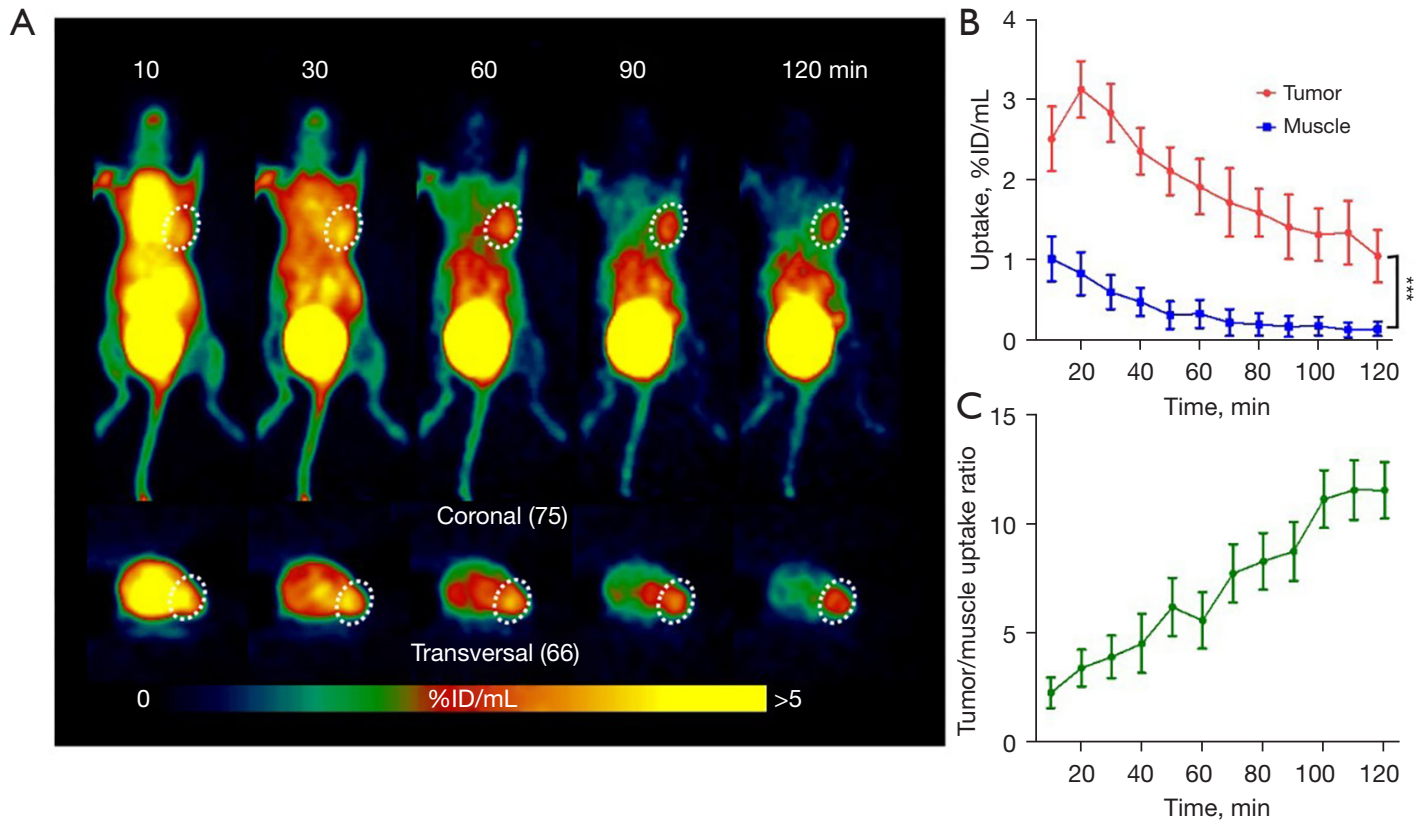

Figure 2 Immuno-PET imaging of PDX LU6424 with $\left[{ }^{68} \mathrm{Ga}\right] \mathrm{Ga}-\mathrm{NOTA}-\mathrm{Nb} 109$ (n=3). (A) Representative coronal and transversal PET images of the LU6424 tumor at different times post-injection. The tumor is indicated by the dotted line circle. (B) The time course of $\left.{ }^{68} \mathrm{Ga}\right]$ Ga-NOTA-Nb109 accumulation in the tumor and the muscles. (C) The time course of tumor/muscle radiotracer uptake ratio in the PDX LU6424 mouse. ***, $\mathrm{P}<0.001$. PET, positron emission tomography; PDX, patient-derived xenograft.

being $1.01 \% \pm 0.28 \% \mathrm{ID} / \mathrm{mL}$ at $10 \mathrm{~min}$ post-injection. As time passed, radiotracer uptake in the muscles decreased and reached an equilibrium value of $0.20 \% \mathrm{ID} / \mathrm{mL}$ after $60 \mathrm{~min}$. Due to the rapid clearance of $\left[{ }^{68} \mathrm{Ga}\right] \mathrm{Ga}-\mathrm{NOTA}-$ $\mathrm{Nb} 109$ from the body, the tumor to muscle radiotracer uptake ratio increased continuously and reached a maximum of $11.55 \pm 1.35$ at $100 \mathrm{~min}$ post-injection (Figure $2 \mathrm{C}$ ).

The PDX LU6437 tumor could be clearly visualized throughout the whole PET imaging process (Figure $3 A$ ), indicating that $\left[{ }^{68} \mathrm{Ga}\right] \mathrm{Ga}-\mathrm{NOTA}-\mathrm{Nb} 109$ can specifically target PD-L1. The ROI analysis showed that the maximum radiotracer uptake within LU6437 was $2.60 \% \pm 0.32 \% \mathrm{ID} / \mathrm{mL}$ at $20 \mathrm{~min}$ post-injection, and gradually decreased over the imaging time (Figure 3B). However, the maximum uptake of tracer in the muscle only reached $1.25 \% \pm 0.25 \% \mathrm{ID} / \mathrm{mL}$ at $20 \mathrm{~min}$ post-injection and decreased slowly over time. Therefore, the tumor to muscle radiotracer uptake ratio increased gradually and reached a plateau of 5.40 at $110 \mathrm{~min}$ post-injection (Figure 3C). For both PDX mouse models, bladder retention was prominent as $\left[{ }^{68} \mathrm{Ga}\right] \mathrm{Ga}$-NOTA$\mathrm{Nb} 109$ was eliminated through the urinary system (Figure $2 A, 3 A)$. These results indicated that $\left[{ }^{68} \mathrm{Ga}\right] \mathrm{Ga}-\mathrm{NOTA}$ $\mathrm{Nb} 109$ can quickly accumulate in the tumor and be cleared from non-target tissues, and hence, a good signal-to-noise ratio (SNR) was obtained.

The PET images in Figures 2,3 show that $\left[{ }^{68} \mathrm{Ga}\right] \mathrm{Ga}$ NOTA-Nb109 also accumulated in healthy tissues, such as the heart, liver, and kidneys. To examine the in vivo distribution and metabolism of $\left[{ }^{68} \mathrm{Ga}\right] \mathrm{Ga}-\mathrm{NOTA}-\mathrm{Nb} 109$ in the PDXs, tracer uptake in normal organ tissues was investigated by dynamic PET scanning (Figure 4). In the PDX mice, $\left[{ }^{68} \mathrm{Ga}\right] \mathrm{Ga}-\mathrm{NOTA}-\mathrm{Nb} 109$ was detected in the heart within the first $10 \mathrm{~min}$ after injection, and the maximum accumulation of radioactivity was $19.93 \% \pm 4.24 \%$ and $20.85 \% \pm 0.99 \% \mathrm{ID} / \mathrm{mL}$ at $10 \mathrm{~min}$ post-injection for LU6424 and LU6437, respectively. The tracer was then quickly cleared from the heart, and the remaining radioactivity at $30 \mathrm{~min}$ post-injection was $2.44 \% \pm 0.39 \% \mathrm{ID} / \mathrm{mL}$ and $4.24 \% \pm 0.32 \% \mathrm{ID} / \mathrm{mL}$ in the PDX LU6424 and PDX LU6437 mice, respectively. By 40 min post-injection, the tracer had almost completely cleared from the heart. Meanwhile, $\left[{ }^{68} \mathrm{Ga}\right] \mathrm{Ga}-\mathrm{NOTA}-$ Nb109 was quickly distributed to the tumor and other tissues, such as the liver and kidneys, through the systemic circulation. The accumulation of $\left[{ }^{68} \mathrm{Ga}\right] \mathrm{Ga}-\mathrm{NOTA}-\mathrm{Nb} 109$ in the liver reached an equilibrium of $1.33 \% \pm 0.31 \%$ ID/ 

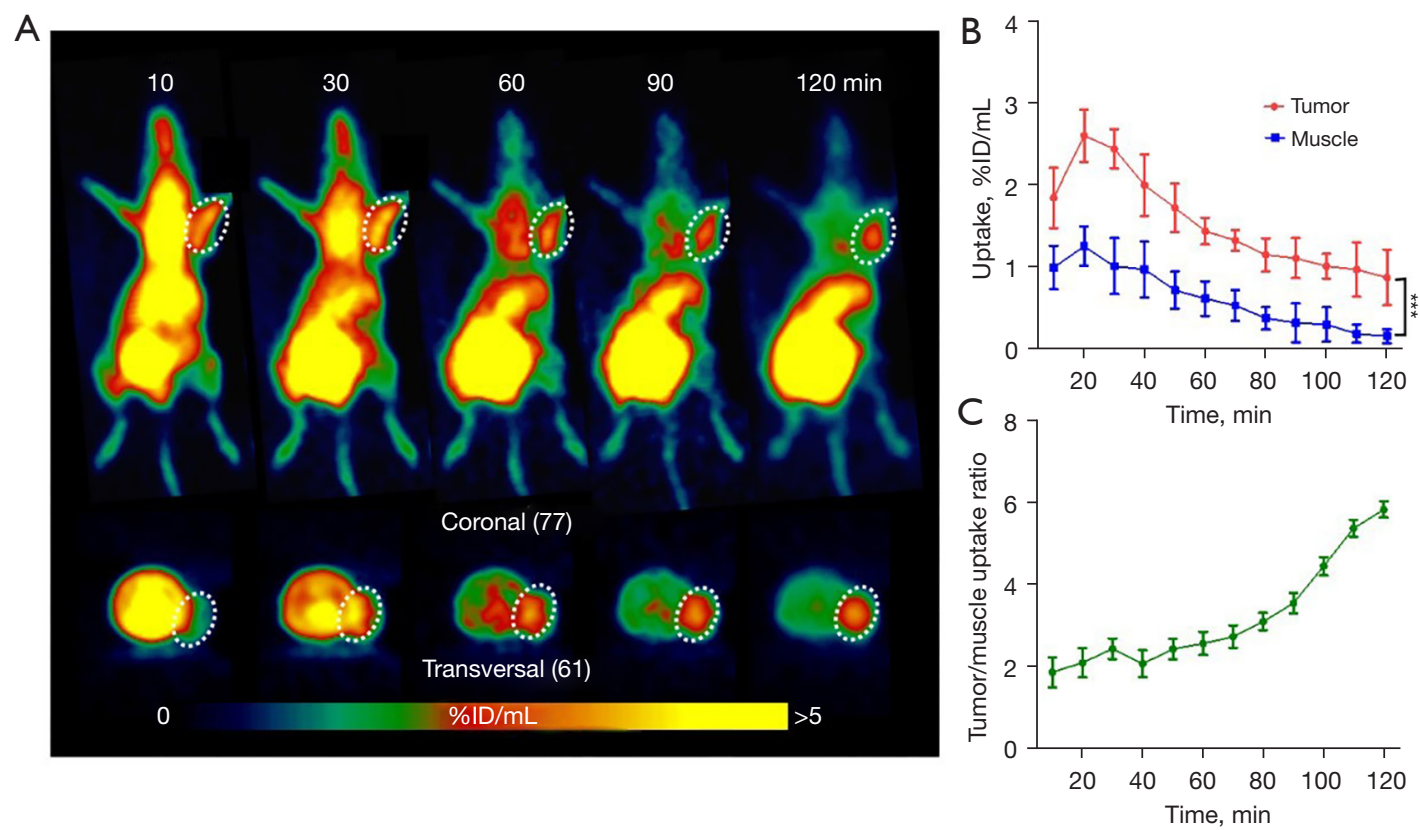

Figure 3 Immuno-PET imaging of PDX LU6437 with $\left[{ }^{68} \mathrm{Ga}\right] \mathrm{Ga}-\mathrm{NOTA}-\mathrm{Nb} 109$ (n=5). (A) Representative coronal and transversal PET images of the LU6437 tumor at different times post-injection. The tumor is indicated by the dotted line circle. (B) The time course of $\left[{ }^{68} \mathrm{Ga}\right]$ Ga-NOTA-Nb109 accumulation in the tumor and the muscles. (C) The time course of tumor/muscle radiotracer uptake ratio in the PDX LU6437 mouse. ${ }^{* * *}, \mathrm{P}<0.001$. PET, positron emission tomography; PDX, patient-derived xenograft.

$\mathrm{mL}$ and $4.67 \% \pm 0.51 \% \mathrm{ID} / \mathrm{mL}$ for LU6424 and LU6437, respectively, at $40 \mathrm{~min}$ post-injection (Figure $4 A, 4 C$ ). In the kidneys, a relatively high radioactive signal was observed for both PDXs. At 10 min post-injection, the kidney retention was $30.91 \% \pm 2.94 \% \mathrm{ID} / \mathrm{mL}$ and $15.51 \% \pm 2.65 \% \mathrm{ID} / \mathrm{mL}$ for LU6424 and LU6437, respectively. Over time, the kidney retention value decreased to $13.51 \% \pm 1.76 \% \mathrm{ID} / \mathrm{mL}$ and $3.67 \% \pm 0.97 \% \mathrm{ID} / \mathrm{mL}$ for LU6424 and LU6437, respectively, and achieved an equilibrium at $40 \mathrm{~min}$ postinjection. This suggested that the tracer was mainly cleared via the renal pathway, and was supported by the gradual accumulation of radioactivity in the bladder throughout the course of the PET imaging process (Figure 2A,3A).

\section{Ex vivo biodistribution analysis}

To further investigate the biodistribution of $\left[{ }^{68} \mathrm{Ga}\right]$ Ga-NOTA-Nb109 in vivo and to validate the PET quantification analysis, ex vivo biodistribution of $\left[{ }^{68} \mathrm{Ga}\right] \mathrm{Ga}-$ NOTA-Nb109 in the 2 PDXs, LU6424 and LU6437, at 60 min post-injection was determined using static PET scanning for $10 \mathrm{~min}$ (Figure 5). For PDX LU6424 (Figure $5 A)$, the PET images illustrated that the accumulation of radioactivity was mainly concentrated in the tumor and the kidneys, which was determined to be $2.17 \% \pm 0.15 \%$ and $9.18 \% \pm 1.30 \% \mathrm{ID} / \mathrm{mL}$ with decay-correction, respectively (Figure 5B). The uptake in other normal organs, such as the heart, lung, and spleen, was lower than that in the tumor, which was in agreement with the in vivo PET imaging data. An obvious radioactive signal near the tumor location was noted (Figure 5A), indicating that the PD-L1 expression was upregulated in pericarcinomatous tissues affected by the tumor.

In the PDX LU6437 mice, radiotracer uptake by the liver was the highest (Figure 5C) with decay-corrected radioactivity of $5.07 \% \pm 0.29 \% \mathrm{ID} / \mathrm{mL}$, followed by the kidneys with radiotracer retention of $4.77 \% \pm 0.63 \% \mathrm{ID} / \mathrm{mL}$ (Figure 5D). The radioactive signal in the LU6437 tumor (Figure 5C) suggested that the PD-L1 expression was heterogeneous and the mean radiotracer uptake by the tumor was $1.61 \% \pm 0.28 \% \mathrm{ID} / \mathrm{mL}$. In addition, it was noted that the radioactivity was rather high in the head and neck, which may be attributed to the tracer uptake by peripheral nodes (44). For both PDXs, $\left[{ }^{68} \mathrm{Ga}\right] \mathrm{Ga}-\mathrm{NOTA}-\mathrm{Nb} 109$ was rapidly cleared from the kidneys, and the deviation in uptake values may be attributed to differences of ADC 

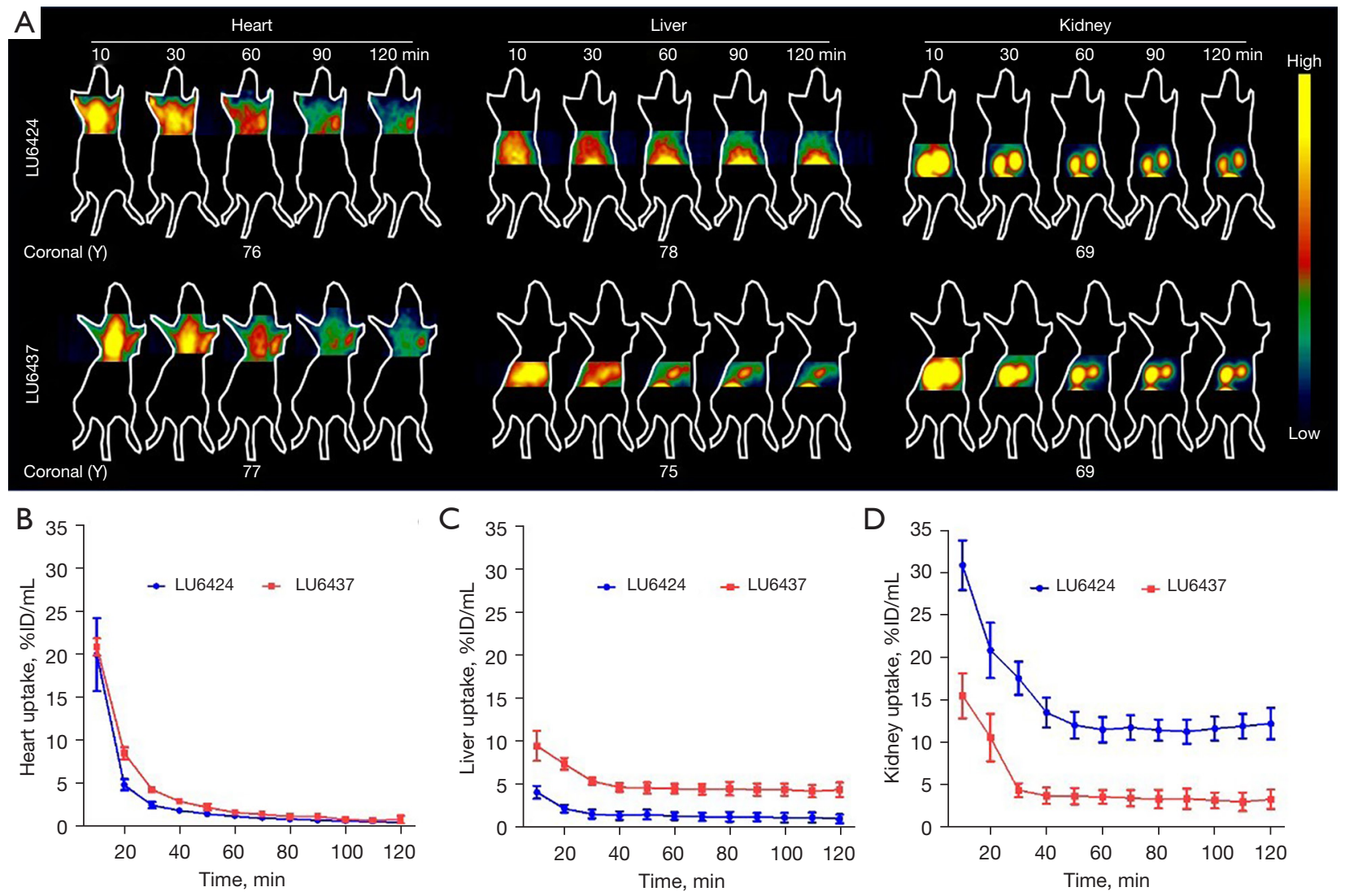

Figure 4 The in vivo distribution and metabolism of $\left[{ }^{68} \mathrm{Ga}\right] \mathrm{Ga}-N O T A-N b 109$ in the LU6424 (n=3) and LU6437 ( $=5$ ) PDXs based on dynamic PET scanning. (A) Representative coronal PET images of the organs (heart, liver, and kidneys) in LU6424 and LU6437 PDX mice. (B-D) The time course of radiotracer uptake and retention in the (B) heart, (C) liver, and (D) kidneys of the LU6424 and LU6437 PDX mice. PDX, patient-derived xenograft; PET, positron emission tomography.

and SCC PDX models. Overall, the ex vivo biodistribution study demonstrated favorable radiotracer uptake by the tumor, rapid radiotracer clearance from the blood, and renal excretion of $\left[{ }^{68} \mathrm{Ga}\right] \mathrm{Ga}-\mathrm{NOTA}-\mathrm{Nb} 109$, all of which are consistent with the in vivo PET imaging results.

\section{Ex vivo PD-L1 expression analysis}

To further quantify the accumulation of $\left[{ }^{68} \mathrm{Ga}\right] \mathrm{Ga}$-NOTA$\mathrm{Nb} 109$ in the tumor, autoradiography analysis was performed (Figure 6A). The radioactive signal in the PDX tumors was significantly higher than that in the muscles, and the grayscale analysis showed that the tracer uptake in the LU6424 and LU6437 tumors were approximately 5.4- to 4.2-fold higher than that observed in the muscles, respectively. In addition, an uneven distribution of the tracer was noted in LU6437, and this was consistent with the results from the ex vivo PET imaging. Furthermore, the PD-L1 expression in the 2 PDXs was assessed by western blot analysis (Figure 6B). The results demonstrated that the PD-L1 expression levels in the LU6424 and LU6437 tumors were both higher than that in the muscles (5.6- and 3.6-fold higher, respectively). Meanwhile, IHC analysis also demonstrated that PD-L1 was overexpressed in the LU6424 and LU6437 tumors, and PD-L1 expression in LU6437 was uneven (Figure 6C). The results of the ex vivo PD-L1 expression analysis were in good agreement with the in vivo PET imaging data.

\section{Discussion}

Lung cancer remains the common cause of cancer death, and early diagnosis and treatment are crucial for improved patient outcomes. Although chemotherapy has shown 

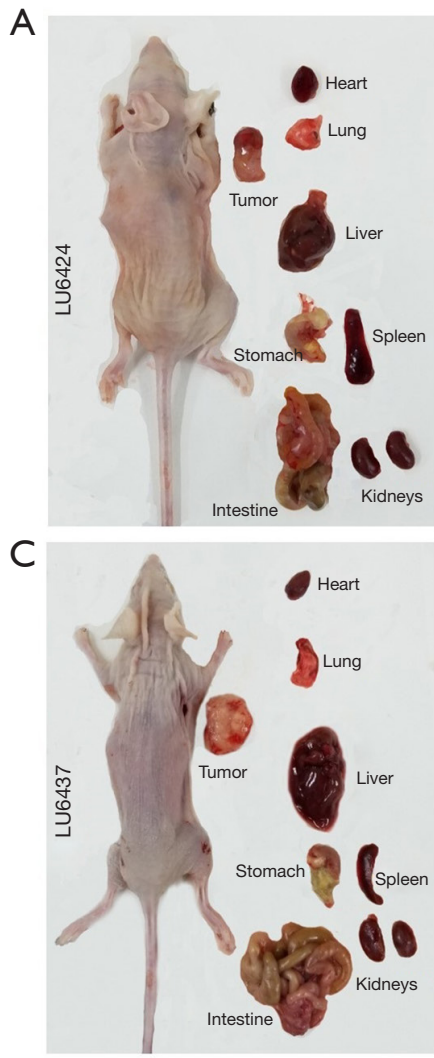
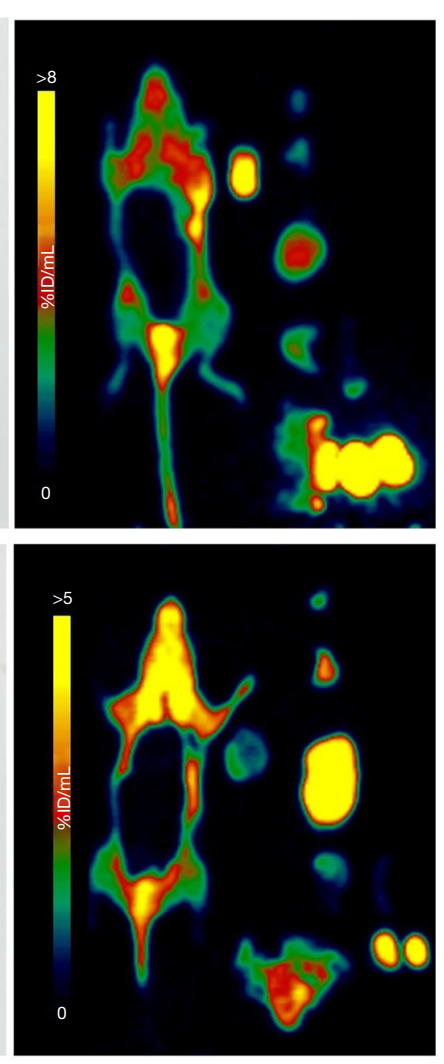

B
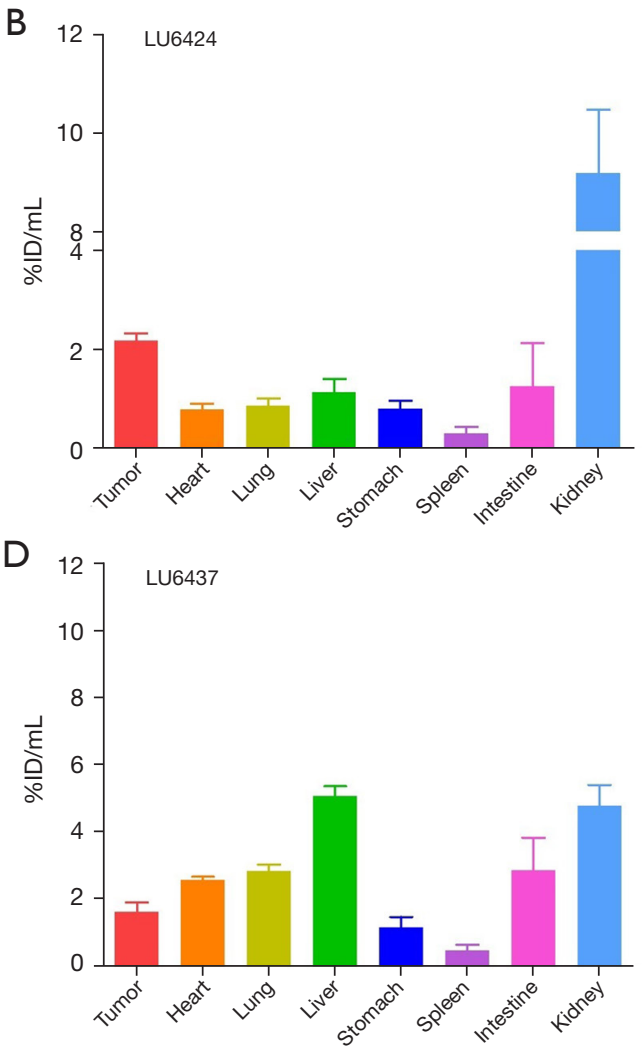

Figure 5 The ex vivo analysis of the biodistribution of $\left[{ }^{68} \mathrm{Ga}\right] \mathrm{Ga}-\mathrm{NOTA}-\mathrm{Nb} 109$ in the LU6424 (n=3) and LU6437 (n=5) PDX mice based on static PET scanning. $(\mathrm{A}, \mathrm{C})$ The ex vivo PET imaging of the tumor and the normal tissues at 1 hour post-injection of $\left[{ }^{68} \mathrm{Ga}\right] \mathrm{Ga}-\mathrm{NOTA}$ Nb109. (B,D) The decay-corrected ROI analysis of the PET signal in the tumor and the normal tissues of the LU6424 and LU6437 PDX mice at 1 hour post-injection. PDX, patient-derived xenograft; PET, positron emission tomography; ROI, region of interest.

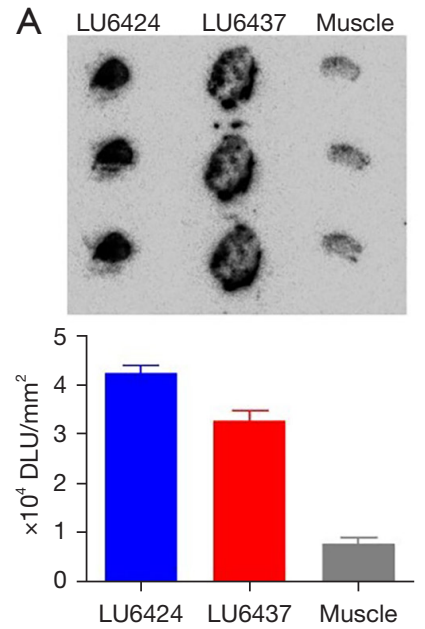

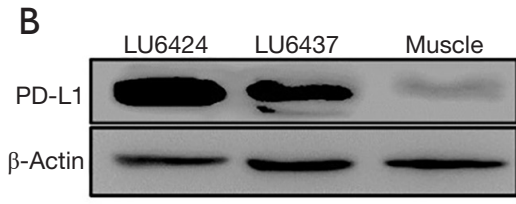

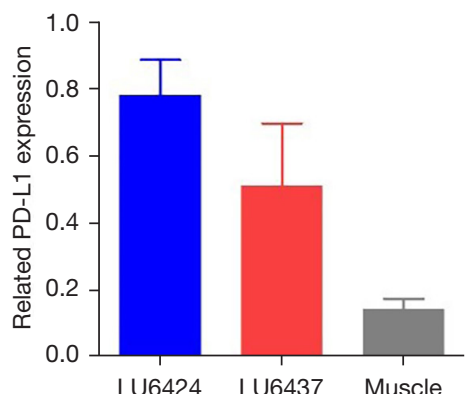

C $50 \mathrm{kDa}$ $42 \mathrm{kDa}$

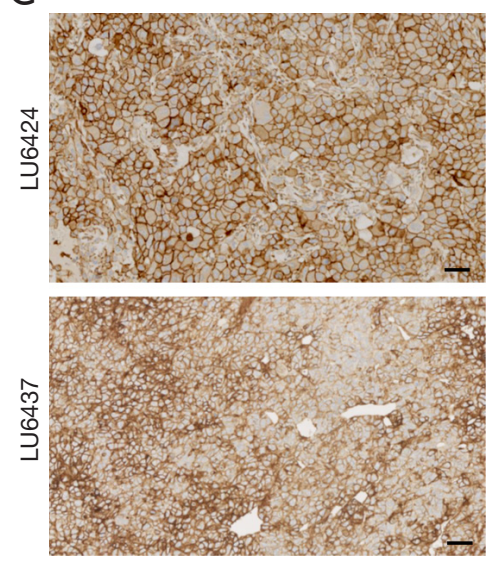

Figure 6 The ex vivo analysis of PD-L1 expression in the LU6424 PDX (n=3) and the LU6437 PDX (n=5). (A) Autoradiography analysis of the tumors and muscles at 1 hour post-injection of $\left[{ }^{68} \mathrm{Ga}\right] \mathrm{Ga}$-NOTA-Nb109. (B) Western blot analysis of PD-L1 expression $(50 \mathrm{kDa})$ in the tumors and muscles with $\beta$-actin $(42 \mathrm{kDa}$ ) as the internal reference. (C) IHC analysis of the tumors in the LU6424 and LU6437 PDX models. Scale bar =20 $\mu \mathrm{m}$. PD-L1, programmed death-ligand 1; PDX, patient-derived xenograft; IHC, immunohistochemical. 
certain benefits to lung cancer patients, the tumor-specific cellular responses to chemotherapeutic drugs are often unsatisfactory. Immunotherapy is an effective cancer treatment strategy, and immune checkpoint-based therapies targeting the PD-1/PD-L1 pathway have demonstrated durable anti-tumor responses $(45,46)$. To date, the treatment of NSCLC patients with immunotherapy has produced remarkable results $(15,25,47,48)$. However, not all patients with NSCLC respond to anti-PD-1/PD-L1 immunotherapy, and serious immune-related side effects have also been reported, which might be attributed to the excessive immune activation in NSCLC patients (49-51). Therefore, accurate assessment of the PD-L1 expression in NSCLC patients may play an important role in identifying immune-responsive patients, thereby reducing the risk of patients exposed to autoimmunity and improving the prognosis of patients undergoing immunotherapy.

While IHC is widely used for the clinical evaluation of PD-L1 expression, the results can be affected by many variables (27), such as reliability of specimens, the selection of antibodies, criteria of scoring PD-L1 expression, and so on. Furthermore, PD-L1 expression can also be influenced by factors such as cytokines, radiotherapy, and chemotherapy (40,52-54). Since noninvasive imaging techniques can evaluate the expression of molecular targets in vivo, various PET imaging tracers targeting PD-L1 have been developed. Immuno-PET tracers based on mAbs have been investigated for preclinical and clinical applications. However, due to the long biological half-life of mAbs and the radionuclide (such as ${ }^{64} \mathrm{Cu}$ and ${ }^{89} \mathrm{Zr}$ ), several days are required to obtain satisfactory images $(31,32)$. Our previous studies identified a nanobody-based immuno-PET tracer $\left[{ }^{68} \mathrm{Ga}\right] \mathrm{Ga}$-NOTANb109 with specificity to PD-L1 $(39,40)$. Both in vitro and in vivo studies were performed using cell lines and cell-line derived xenografts (CDXs). However, the CDXs did not accurately represent the heterogeneity of the tumor and these studies resulted in low clinical relevance (55). Therefore, PDX animal models that retain the biological characteristics of the original tumor are needed to accurately evaluate the clinical application of $\left[{ }^{68} \mathrm{Ga}\right] \mathrm{Ga}-\mathrm{NOTA}-\mathrm{Nb} 109$. Indeed, PDX models may preserve more complete genetic and oncologic features, maintain the stromal and stem cell components of the tumor, and retain the heterogeneity of the target receptor expression (56). Therefore, PDXs derived from patients with NSCLC were constructed and employed to evaluate the clinical value of $\left[{ }^{68} \mathrm{Ga}\right] \mathrm{Ga}-\mathrm{NOTA}-\mathrm{Nb} 109$.

The present study used ADC and SCC for the PDX models due to the higher incidences of these lung cancer subtypes. The $C D 274$ gene encodes the PD-L1 protein, and thus, the expression of the CD274 gene can reflect the level of PD-L1 expression to a certain extent. The analysis of CD274 expression (Table 1) showed that both ADC and SCC had high PD-L1 expression. Although there was no difference in the genotype (CD274 expression level) between the 2 lung cancer types, the phenotype (PD-L1 expression level) showed a visible difference (Figure 6B,6C) that could be accurately detected by $\left[{ }^{68} \mathrm{Ga}\right] \mathrm{Ga}-\mathrm{NOTA}-$ Nb109 uptake (Figures 2,3,6A).

Western blot analysis revealed that the PDX tumors showed high PD-L1 expression, in agreement with the IHC data. Tumors in both PDXs had high radioactive signal at 20 min post-injection, which was comparable to radiotracer uptake in U87 CDXs with high PD-L1 expression (CDXs, cell-line derived xenografts) (40). Meanwhile, a satisfactory SNR was obtained in the PDXs, which may be due to the characteristics of the nanobodies, such as low molecular weight, high stability, deep tissue penetration, and weak immunogenicity (57).

Although the biodistribution of the tracer was investigated in a previous study (39), it was necessary to assess the biocompatibility of the probe within different models. The biodistribution analysis of $\left[{ }^{68} \mathrm{Ga}\right] \mathrm{Ga}$ NOTA-Nb109 in vivo and ex vivo showed that $\left[{ }^{68} \mathrm{Ga}\right]$ Ga-NOTA-Nb109 quickly accumulated in the heart and was transported to the target site through the circulatory system. The tracer then bound specifically with PDL1 in the tumor, while the unbound tracer was quickly cleared from the body via the renal pathway, resulted in a satisfactory visualization of the tumor at 1 hour postinjection. However, there was an obvious difference in the background uptake between the two PDXs, especially in the liver and kidneys. This might be attributed to the variations of ADC and SCC PDX models. Compared to traditional mAb-based PET tracers, nanobody-based tracers have high biocompatibility, feasibility, and safety in humans, which makes them ideal candidates for clinical application. These results demonstrated that immuno-PET imaging with $\left[{ }^{68} \mathrm{Ga}\right] \mathrm{Ga}-\mathrm{NOTA}-\mathrm{Nb} 109$ is a reliable and non-invasive technique to accurately detect PD-L1 expression and to screen patients who are likely to have a positive response to immunotherapy. This is conducive for improving the response rate of immunotherapy.

\section{Conclusions}

To further evaluate the clinical value of immuno-PET 
imaging with $\left[{ }^{68} \mathrm{Ga}\right] \mathrm{Ga}-\mathrm{NOTA}-\mathrm{Nb} 109$, its sensitivity and accuracy in monitoring the PD-L1 expression in NSCLC PDX models were investigated in this study. Both in vivo and ex vivo experimental results demonstrated that the tracer $\left[{ }^{68} \mathrm{Ga}\right] \mathrm{Ga}-\mathrm{NOTA}-\mathrm{Nb} 109$ can accurately and sensitively detect the PD-L1 expression in PDXs of lung cancer. In addition, $\left[{ }^{68} \mathrm{Ga}\right] \mathrm{Ga}-\mathrm{NOTA}-\mathrm{Nb} 109$ could be rapidly cleared via renal excretion in a short time and a clear PET image with high SNR was obtained. This will be beneficial for screening patients who may have an effective response to immunotherapy, thereby improving the overall cure rate of cancer patients. The present study provides a solid basis for the ongoing clinical research of $\left[{ }^{68} \mathrm{Ga}\right] \mathrm{Ga}$ NOTA-Nb109. Furthermore, the successful application of PDX models may facilitate future clinical trials and allow for the evaluation of tumor characteristics in individual patients.

\section{Acknowledgments}

Funding: This study was supported by the National Natural Science Foundation of China (No. 22076069), the Natural Science Foundation of Jiangsu Province (Nos. BK20181128 and BK20201135), the Major Scientific Research Project of Jiangsu Commission of Health (No. ZDA2020007), the Major Scientific Research Project of Wuxi Commission of Health (No. Z201913), the Science Technology and Development Project of Wuxi (No. Y20212013), and the Scientific Research Project of Jiangsu Commission of Health (No. M2020028).

\section{Footnote}

Reporting Checklist: The authors have completed the Guidelines for Reporting Reliability and Agreement Studies (GRRAS) reporting checklist. Available at https://qims. amegroups.com/article/view/10.21037/qims-21-991/rc

Conflicts of Interest: All authors have completed the ICMJE uniform disclosure form (available at https://qims. amegroups.com/article/view/10.21037/qims-21-991/ coif). QL received funding from the Scientific Research Project of Jiangsu Commission of Health (No. M2020028). JL received funding from the National Natural Science Foundation of China (No. 22076069), the Natural Science Foundation of Jiangsu Province (No. BK20201135), and the Major Scientific Research Project of Jiangsu Commission of Health (No. ZDA2020007). LQ received funding from the Natural Science Foundation of Jiangsu Province (No. BK20181128), the Science Technology and Development Project of Wuxi (No. Y20212013), and the Major Scientific Research Project of Wuxi Commission of Health (No. Z201913). YY and CW were employed by Suzhou Smart Nuclide Biopharmaceutical Co. Ltd. (Suzhou, China). The other authors have no conflicts of interest to declare.

Ethical Statement: The authors are accountable for all aspects of the work in ensuring that questions related to the accuracy or integrity of any part of the work are appropriately investigated and resolved. This study was approved by the Institutional Ethics Board of Jiangsu Institute of Nuclear Medicine, in compliance with the Laboratory Animal Guidelines for the Ethical Review of Animal Welfare of China (No. GB/T 35892-2018).

Open Access Statement: This is an Open Access article distributed in accordance with the Creative Commons Attribution-NonCommercial-NoDerivs 4.0 International License (CC BY-NC-ND 4.0), which permits the noncommercial replication and distribution of the article with the strict proviso that no changes or edits are made and the original work is properly cited (including links to both the formal publication through the relevant DOI and the license). See: https://creativecommons.org/licenses/by-nc-nd/4.0/.

\section{References}

1. Sung H, Ferlay J, Siegel RL, Laversanne M, Soerjomataram I, Jemal A, Bray F. Global Cancer Statistics 2020: GLOBOCAN Estimates of Incidence and Mortality Worldwide for 36 Cancers in 185 Countries. CA Cancer J Clin 2021;71:209-49.

2. Chua GWY, Chua KLM. Which patients benefit most from stereotactic body radiotherapy or surgery in medically operable non-small cell lung cancer? An indepth look at patient characteristics on both sides of the debate. Thorac Cancer 2019;10:1857-67.

3. Rizvi NA, Chul Cho B, Reinmuth N, Lee KH, Ahn MJ, Luft A, van den Heuvel M, Cobo M, Smolin A, Vicente D, Moiseyenko V, Antonia SJ, Le Moulec S, Robinet G, Natale R, Nakagawa K, Zhao L, Stockman PK, Chand V, Peters S. Durvalumab with or without tremelimumab vs platinum-based chemotherapy as first-line treatment for metastatic non-small cell lung cancer: MYSTIC. Ann Oncol 2018;29:x40-1.

4. Gandhi L, Rodríguez-Abreu D, Gadgeel S, Esteban 
E, Felip E, De Angelis F, et al. Pembrolizumab plus Chemotherapy in Metastatic Non-Small-Cell Lung Cancer. N Engl J Med 2018;378:2078-92.

5. Yuan M, Huang LL, Chen JH, Wu J, Xu Q. The emerging treatment landscape of targeted therapy in non-small-cell lung cancer. Signal Transduct Target Ther 2019;4:61.

6. Allemani C, Matsuda T, Di Carlo V, Harewood R, Matz M, Nikšić M, et al. Global surveillance of trends in cancer survival 2000-14 (CONCORD-3): analysis of individual records for 37513025 patients diagnosed with one of 18 cancers from 322 population-based registries in 71 countries. Lancet 2018;391:1023-75.

7. Quesada JR, Hersh EM, Manning J, Reuben J, Keating M, Schnipper E, Itri L, Gutterman JU. Treatment of hairy cell leukemia with recombinant alpha-interferon. Blood 1986;68:493-7.

8. Rosenberg SA. IL-2: the first effective immunotherapy for human cancer. J Immunol 2014;192:5451-8.

9. Brahmer JR, Pardoll DM. Immune checkpoint inhibitors: making immunotherapy a reality for the treatment of lung cancer. Cancer Immunol Res 2013;1:85-91.

10. Riley RS, June CH, Langer R, Mitchell MJ. Delivery technologies for cancer immunotherapy. Nat Rev Drug Discov 2019;18:175-96.

11. Singh AK, McGuirk JP. CAR T cells: continuation in a revolution of immunotherapy. Lancet Oncol 2020;21:e168-78.

12. He J, Hu Y, Hu M, Li B. Development of PD-1/PDL1 Pathway in Tumor Immune Microenvironment and Treatment for Non-Small Cell Lung Cancer. Sci Rep 2015;5:13110.

13. Ancevski Hunter K, Socinski MA, Villaruz LC. PDL1 Testing in Guiding Patient Selection for PD-1/PDL1 Inhibitor Therapy in Lung Cancer. Mol Diagn Ther 2018;22:1-10.

14. Meng X, Liu Y, Zhang J, Teng F, Xing L, Yu J. PD-1/ PD-L1 checkpoint blockades in non-small cell lung cancer: New development and challenges. Cancer Lett 2017;405:29-37.

15. Sacher AG, Gandhi L. Biomarkers for the Clinical Use of PD-1/PD-L1 Inhibitors in Non-Small-Cell Lung Cancer: A Review. JAMA Oncol 2016;2:1217-22.

16. Xin Yu J, Hodge JP, Oliva C, Neftelinov ST, HubbardLucey VM, Tang J. Trends in clinical development for PD-1/PD-L1 inhibitors. Nat Rev Drug Discov 2020;19:163-4.

17. Al Mamun A, Mei Z, Qiu L, Ju X. Theoretical investigation on QSAR of (2-Methyl-3-biphenylyl) methanol analogs as PD-L1 inhibitor. Chinese Journal of Chemical Physics 2020;33:459-67.

18. Carbone DP, Reck M, Paz-Ares L, Creelan B, Horn L, Steins M, et al. First-Line Nivolumab in Stage IV or Recurrent Non-Small-Cell Lung Cancer. N Engl J Med 2017;376:2415-26.

19. Garon EB, Rizvi NA, Hui R, Leighl N, Balmanoukian AS, Eder JP, et al. Pembrolizumab for the treatment of nonsmall-cell lung cancer. N Engl J Med 2015;372:2018-28.

20. Rittmeyer A, Barlesi F, Waterkamp D, Park K, Ciardiello F, von Pawel J, et al. Atezolizumab versus docetaxel in patients with previously treated non-small-cell lung cancer (OAK): a phase 3, open-label, multicentre randomised controlled trial. Lancet 2017;389:255-65.

21. Patel SP, Kurzrock R. PD-L1 Expression as a Predictive Biomarker in Cancer Immunotherapy. Mol Cancer Ther 2015;14:847-56.

22. Cheng M, Durm G, Hanna N, Einhorn LH, Kong FS. Can radiotherapy potentiate the effectiveness of immune checkpoint inhibitors in lung cancer? Future Oncol 2017;13:2503-5.

23. Hellmann MD, Rizvi NA, Goldman JW, Gettinger SN, Borghaei H, Brahmer JR, Ready NE, Gerber DE, Chow LQ, Juergens RA, Shepherd FA, Laurie SA, Geese WJ, Agrawal S, Young TC, Li X, Antonia SJ. Nivolumab plus ipilimumab as first-line treatment for advanced non-smallcell lung cancer (CheckMate 012): results of an open-label, phase 1, multicohort study. Lancet Oncol 2017;18:31-41.

24. Zhou ZJ, Zhan P, Song Y. PD-L1 over-expression and survival in patients with non-small cell lung cancer: a meta-analysis. Transl Lung Cancer Res 2015;4:203-8.

25. Bustamante Alvarez JG, González-Cao M, Karachaliou N, Santarpia M, Viteri S, Teixidó C, Rosell R. Advances in immunotherapy for treatment of lung cancer. Cancer Biol Med 2015;12:209-22.

26. Fehrenbacher L, Spira A, Ballinger M, Kowanetz M, Vansteenkiste J, Mazieres J, Park K, Smith D, Artal-Cortes A, Lewanski C, Braiteh F, Waterkamp D, He P, Zou W, Chen DS, Yi J, Sandler A, Rittmeyer A; POPLAR Study Group. Atezolizumab versus docetaxel for patients with previously treated non-small-cell lung cancer (POPLAR): a multicentre, open-label, phase 2 randomised controlled trial. Lancet 2016;387:1837-46.

27. Tsao MS, Kerr KM, Kockx M, Beasley MB, Borczuk AC, Botling J, et al. PD-L1 Immunohistochemistry Comparability Study in Real-Life Clinical Samples: Results of Blueprint Phase 2 Project. J Thorac Oncol 2018;13:1302-11. 
28. Expert Group on PD-L1 Testing Consensus. Chinese Expert Consensus on Standards of PD-L1 Immunohistochemistry Testing for Non-small Cell Lung Cancer. Zhongguo Fei Ai Za Zhi 2020;23:733-40.

29. O'Malley DP, Yang Y, Boisot S, Sudarsanam S, Wang JF, Chizhevsky V, Zhao G, Arain S, Weiss LM. Immunohistochemical detection of PD-L1 among diverse human neoplasms in a reference laboratory: observations based upon 62,896 cases. Mod Pathol 2019;32:929-42.

30. van der Veen EL, Giesen D, Pot-de Jong L, JorritsmaSmit A, De Vries EGE, Lub-de Hooge MN. ${ }^{89} \mathrm{Zr}-$ pembrolizumab biodistribution is influenced by PD1-mediated uptake in lymphoid organs. J Immunother Cancer 2020;8:e000938.

31. Lesniak WG, Chatterjee S, Gabrielson M, Lisok A, Wharram B, Pomper MG, Nimmagadda S. PD-L1 Detection in Tumors Using $\left[{ }^{64} \mathrm{Cu}\right]$ Atezolizumab with PET. Bioconjug Chem 2016;27:2103-10.

32. Bensch F, van der Veen EL, Lub-de Hooge MN, Jorritsma-Smit A, Boellaard R, Kok IC, et al. ${ }^{89} \mathrm{Zr}-$ atezolizumab imaging as a non-invasive approach to assess clinical response to PD-L1 blockade in cancer. Nat Med 2018;24:1852-8.

33. Jagoda EM, Vasalatiy O, Basuli F, Opina ACL, Williams MR, Wong K, Lane KC, Adler S, Ton AT, Szajek LP, Xu B, Butcher D, Edmondson EF, Swenson RE, Greiner J, Gulley J, Eary J, Choyke PL. Immuno-PET Imaging of the Programmed Cell Death-1 Ligand (PD-L1) Using a Zirconium-89 Labeled Therapeutic Antibody, Avelumab. Mol Imaging 2019;18:1536012119829986.

34. Chatterjee S, Lesniak WG, Miller MS, Lisok A, Sikorska E, Wharram B, Kumar D, Gabrielson M, Pomper MG, Gabelli SB, Nimmagadda S. Rapid PD-L1 detection in tumors with PET using a highly specific peptide. Biochem Biophys Res Commun 2017;483:258-63.

35. Kumar D, Lisok A, Dahmane E, McCoy M, Shelake S, Chatterjee S, Allaj V, Sysa-Shah P, Wharram B, Lesniak WG, Tully E, Gabrielson E, Jaffee EM, Poirier JT, Rudin CM, Gobburu JV, Pomper MG, Nimmagadda S. Peptidebased PET quantifies target engagement of PD-L1 therapeutics. J Clin Invest 2019;129:616-30.

36. De Silva RA, Kumar D, Lisok A, Chatterjee S, Wharram B, Venkateswara Rao K, Mease R, Dannals RF, Pomper MG, Nimmagadda S. Peptide-Based ${ }^{68}$ Ga-PET Radiotracer for Imaging PD-L1 Expression in Cancer. Mol Pharm 2018;15:3946-52.

37. Lv G, Miao Y, Chen Y, Lu C, Wang X, Xie M, Qiu L, Lin J. Promising potential of a ${ }^{18} \mathrm{~F}$-labelled small-molecular radiotracer to evaluate $\mathrm{PD}-\mathrm{L} 1$ expression in tumors by PET imaging. Bioorg Chem 2021;115:105294.

38. Miao Y, Lv G, Chen Y, Qiu L, Xie M, Lin J. One-step radiosynthesis and initial evaluation of a small molecule PET tracer for PD-L1 imaging. Bioorg Med Chem Lett 2020;30:127572.

39. Lv G, Sun X, Qiu L, Sun Y, Li K, Liu Q, Zhao Q, Qin S, Lin J. PET Imaging of Tumor PD-L1 Expression with a Highly Specific Nonblocking Single-Domain Antibody. J Nucl Med 2020;61:117-22.

40. Liu Q, Jiang L, Li K, Li H, Lv G, Lin J, Qiu L. ImmunoPET imaging of ${ }^{68} \mathrm{Ga}$-labeled nanobody Nb109 for dynamic monitoring the PD-L1 expression in cancers. Cancer Immunol Immunother 2021;70:1721-33.

41. Herbst RS, Morgensztern D, Boshoff C. The biology and management of non-small cell lung cancer. Nature 2018;553:446-54.

42. Shen H, Chen L, Liu K, Zhao K, Li J, Yu L, Ye H, Zhu W. A subregion-based positron emission tomography/ computed tomography (PET/CT) radiomics model for the classification of non-small cell lung cancer histopathological subtypes. Quant Imaging Med Surg 2021;11:2918-32.

43. Wang BY, Huang JY, Chen HC, Lin CH, Lin SH, Hung WH, Cheng YF. The comparison between adenocarcinoma and squamous cell carcinoma in lung cancer patients. J Cancer Res Clin Oncol 2020;146:43-52.

44. Van den Broeck W, Derore A, Simoens P. Anatomy and nomenclature of murine lymph nodes: Descriptive study and nomenclatory standardization in $\mathrm{BALB} / \mathrm{cAnNCrl}$ mice. J Immunol Methods 2006;312:12-9.

45. Pons-Tostivint E, Latouche A, Vaflard P, Ricci F, Loirat D, Hescot S, Sablin M, Rouzier R, Kamal M, Morel C, Lecerf C, Servois V, Paoletti X, Tourneau C. Comparative Analysis of Durable Responses on Immune Checkpoint Inhibitors Versus Other Systemic Therapies: A Pooled Analysis of Phase III Trials. JCO Precis Oncol 2019;3:1-10.

46. Brahmer JR, Govindan R, Anders RA, Antonia SJ, Sagorsky S, Davies MJ, et al. The Society for Immunotherapy of Cancer consensus statement on immunotherapy for the treatment of non-small cell lung cancer (NSCLC). J Immunother Cancer 2018;6:75.

47. Garon EB. Current Perspectives in Immunotherapy for Non-Small Cell Lung Cancer. Semin Oncol 2015;42 Suppl 2:S11-8.

48. Scarpace SL. Metastatic squamous cell non-small-cell lung cancer (NSCLC): disrupting the drug treatment paradigm 
with immunotherapies. Drugs Context 2015;4:212289.

49. Luo $W$, Wang $Z$, Tian $P$, Li W. Safety and tolerability of PD-1/PD-L1 inhibitors in the treatment of non-small cell lung cancer: a meta-analysis of randomized controlled trials. J Cancer Res Clin Oncol 2018;144:1851-9.

50. Wang L, Ma Q, Yao R, Liu J. Current status and development of anti-PD-1/PD-L1 immunotherapy for lung cancer. Int Immunopharmacol 2020;79:106088.

51. Fang T, Xiao J, Zhang Y, Hu H, Zhu Y, Cheng Y. Combined with interventional therapy, immunotherapy can create a new outlook for tumor treatment. Quant Imaging Med Surg 2021;11:2837-60.

52. Gao H, Wu Y, Shi J, Zhang X, Liu T, Hu B, Jia B, Wan Y, Liu Z, Wang F. Nuclear imaging-guided PD-L1 blockade therapy increases effectiveness of cancer immunotherapy. J Immunother Cancer 2020;8:e001156.

Cite this article as: Liu Q, Wang X, Yang Y, Wang C, Zou J, Lin J, Qiu L. Immuno-PET imaging of PD-L1 expression in patient-derived lung cancer xenografts with $\left[{ }^{68} \mathrm{Ga}\right] \mathrm{Ga}-\mathrm{NOTA}$ Nb109. Quant Imaging Med Surg 2022;12(6):3300-3313. doi: 10.21037/qims-21-991
53. Ehlerding EB, Lee HJ, Barnhart TE, Jiang D, Kang L, McNeel DG, Engle JW, Cai W. Noninvasive Imaging and Quantification of Radiotherapy-Induced PD-L1 Upregulation with ${ }^{89} \mathrm{Zr}$-Df-Atezolizumab. Bioconjug Chem 2019;30:1434-41.

54. Zhang C, Zhang K, Gu J, Ge D. ENO1 promotes antitumor immunity by destabilizing PD-L1 in NSCLC. Cell Mol Immunol 2021;18:2045-7.

55. Cho SY. Patient-derived xenografts as compatible models for precision oncology. Lab Anim Res 2020;36:14.

56. Jung J. Human tumor xenograft models for preclinical assessment of anticancer drug development. Toxicol Res 2014;30:1-5.

57. Barar J, Javadzadeh AR, Omidi Y. Ocular novel drug delivery: impacts of membranes and barriers. Expert Opin Drug Deliv 2008;5:567-81. 